\title{
Kajian tentang intensitas cahaya dan konsumsi bahan bakar lampu gas LPG
}

\author{
Study on the light intensity and fuel consumption on LPG gas lamp
}

\author{
GREIS S. DARUIT*, FRANGKY E. KAPARANG dan FransisCo P.T. PANGALILA \\ Program Studi Pemanfaatan Sumberdaya Perikanan, Fakultas Perikanan dan Ilmu Kelautan, \\ Universitas Sam Ratulangi, Manado 95115
}

\begin{abstract}
Utilization of light as fishing apparatus has grown rapidly since the invention of electric lamps, but the lack of fuel availability affects fishing operations. LPG-fueled lamp has come on the market as an alternative solution to replace kerosene lamp. This research was done to compare the light intensity and fuel consumption of LPG-fueled lamp using three different mantle sizes. Mantle A (700-800 c.p.) has light intensity of 83 lux in average, mantles B (500600 c.p.) 74 lux and mantles C (300-400 c.p.) 37 lux. In three-day operation, the lamp with mantle A, B and C consumed 733, 766 and $800 \mathrm{~g}$ fuel in average, respectively. Mantle A has the highest light intensity and lowest fuel consumption.
\end{abstract}

Keywords: gas lamp, light fishing, mantles, light intensity, LPG

\begin{abstract}
ABSTRAK
Pemanfaatan lampu sebagai alat bantu penangkapan ikan telah berkembang secara cepat sejak ditemukannya lampu listrik, akan tetapi minimnya ketersedian BBM menjadi faktor yang mempengaruhi operasi penangkapan ikan. Lampu gas berbahan bakar LPG telah hadir dipasaran sebagai alternatif pengganti lampu gas berbahan bakar minyak tanah. Oleh karena itu dilakukan penelitian tentang lampu gas ini dengan tujuan untuk membandingkan intensitas cahaya dan konsumsi bahan bakar yang dihasilkan oleh lampu gas berbahan bakar LPG dengan menggunakan 3 (tiga) ukuran kaos lampu yang berbeda. Kaos lampu A (700-800 c.p.) memiliki nilai intensitas cahaya rata-rata sebesar 83 lux, kaos lampu B (500-600 c.p.) sebesar 74 lux dan kaos lampu C (300-400 c.p.) sebesar 37 lux. Konsumsi bahan bakar selama tiga hari untuk kaos lampu A rata-rata sebesar 733 g, kaos lampu B sebesar $766 \mathrm{~g}$ dan kaos lampu C sebesar $800 \mathrm{~g}$. Kaos lampu A memiliki nilai intensitas cahaya yang lebih tinggi dari kaos lampu B dan kaos lampu C, serta memiliki nilai konsumsi bahan bakar paling sedikit.
\end{abstract}

Kata-kata kunci: lampu gas, light fishing, kaos lampu, intensitas cahaya, LPG

\section{PENDAHULUAN}

Perkembangan ilmu pengetahuan dan teknologi di bidang penangkapan ikan yang relatif cepat, pada akhir-akhir ini menyebabkan semakin dibutuhkannya sumberdaya energi, yang selama ini banyak bergantung pada minyak bumi. Namun disadari bahwa minyak bumi jika terus menerus diambil maka pada akhirnya akan habis, dan untuk dapat memperbaharuinya lagi dibutuhkan waktu yang lama.

\footnotetext{
*Penulis untuk penyuratan; email: greisdaruit@yahoo.co.id
}

Beberapa faktor utama yang berpengaruh pada peningkatan produksi perikanan tangkap adalah ketersediaan sumberdaya ikan, alat tangkap, kapal ikan dan nelayan. Sementara bahan bakar minyak (BBM) menjadi faktor penting dalam menggerakkan kapal ikan serta didukung oleh faktor penunjang seperti ketersediaan dan kenaikan harga BBM. Faktor-faktor tersebut memberikan efek yang signifikan terhadap keberhasilan operasional perikanan tangkap (Rahardjo dkk., 2011).

Peningkatan produksi perikanan tangkap juga dipengaruhi oleh kuantitas dan kualitas beberapa faktor penunjang, namun juga diakui bahwa tidak semua faktor penunjang memiliki pengaruh positif 